\title{
Limited Early T-Cell Differentiation
}

National Cancer Institute

\section{Source}

National Cancer Institute. Limited Early T-Cell Differentiation. NCI Thesaurus. Code C130044.

A finding indicating the presence of neoplastic cells with immunophenotypic and genetic characteristics suggesting limited early $\mathrm{T}$-cell differentiation. 